\title{
TU/e EmonoweN

\section{Contribution of HRC to the study on the chemistry of natural plants, chemotaxonomy, and biodiversity conservation}

\section{Citation for published version (APA):}

Dung, N. X., Huy, D. Q., Khien, P. V., Moi, L. D., Cu, L. D., Nam, V. V., Hac, L. V., Khoi, T. T., \& Leclercq, P. A. (1995). Contribution of HRC to the study on the chemistry of natural plants, chemotaxonomy, and biodiversity conservation. Journal of High Resolution Chromatography, 18(9), 603-606.

https://doi.org/10.1002/jhrc.1240180919

DOI:

10.1002/jhrc. 1240180919

Document status and date:

Published: 01/01/1995

\section{Document Version:}

Publisher's PDF, also known as Version of Record (includes final page, issue and volume numbers)

\section{Please check the document version of this publication:}

- A submitted manuscript is the version of the article upon submission and before peer-review. There can be important differences between the submitted version and the official published version of record. People interested in the research are advised to contact the author for the final version of the publication, or visit the $\mathrm{DOI}$ to the publisher's website.

- The final author version and the galley proof are versions of the publication after peer review.

- The final published version features the final layout of the paper including the volume, issue and page numbers.

Link to publication

\section{General rights}

Copyright and moral rights for the publications made accessible in the public portal are retained by the authors and/or other copyright owners and it is a condition of accessing publications that users recognise and abide by the legal requirements associated with these rights.

- Users may download and print one copy of any publication from the public portal for the purpose of private study or research.

- You may not further distribute the material or use it for any profit-making activity or commercial gain

- You may freely distribute the URL identifying the publication in the public portal.

If the publication is distributed under the terms of Article 25fa of the Dutch Copyright Act, indicated by the "Taverne" license above, please follow below link for the End User Agreement:

www.tue.nl/taverne

Take down policy

If you believe that this document breaches copyright please contact us at:

openaccess@tue.nl

providing details and we will investigate your claim. 


\section{Contribution of HRC to the Study on the Chemistry of Natural Plants, Chemotaxonomy, and Biodiversity Conservation}

Nguyễ̃ Xuân Dung* and Dô Quang Huy

Center for Education and Development of Chromatography (EDC Vietnam), 3 Giái Phóng Street, Quân Hai Bà, 10000 Hanoi, Viêtnam

\section{Pham Van Khiên}

Hanoi College of Pharmacy, 13-15 Lê Thánh Tông Street, 10000 Hanoi, Viêtnam

\section{Lã Dình Mõi, Lu'u Dàm Cu', and Vu Viêt Nam}

National Center for Natural Science and Technology of Vietnam, Tù Liêm, Hanoi, Viêtnarn

Lê Van Hac

Facuity of Chemistry, Vinh Teachers Training College, Nghê An, Viêtnam

Ta Thi Khôi

Faculty of Chemistry, Hanoi National University, Hanoi, Viêtnam

Piet A. Leclereq*

Department of Chemical Engineering, Eindhoven University of Technology, P.O. Box 513, 5600 MB Eindhoven, The Netherlands

\section{Key Words:}

High Resolution GC and GC/MS

Elsholtzia blanda chemotypes

Elsholtzia communis

Perilla frutescens chemotypes

Essential oil compositions

\section{Introduction}

Study of the chemistry of natural products, chemotaxonomy, and biodiversity conservation is a relevant topic today and will play an important role in the future. Humankind's knowledge and understanding of these subjects is still very limited, and many plants and animals are steadily becoming extinct through the influence of humans and nature before they have been studied.

Vietnam is one of the countries well endowed with biodiversity. Its diverse climates and ecosystems, fertile river deltas, forests, and high mountains contribute to the natural richness of biodiversity. Vietnam has vast and very rich resources of medicinal and aromatic plants. This country is also ethnically diverse with a human population living in a variety of cultures. The interaction of this human diversity with nature is responsible for the development and maintenance of biodiversity.

HRC has become one of the most powerful techniques for the analysis of multicomponent mixtures from various origins. The separation of natural products by $\mathrm{HRC}$, in combination with identification by mass spectrometry, is indispensable in establishing a systematic classification of the many plant species occurring in nature. We undertook a systematic investigation to determine the constituents present in the essential oils of medicinal and aromatic plants from Vietnam. In these studies HRGC and HRGC/MS are used for the characterization of the essential oils of various plant species from the families of Lauraceae, Zingiberaceae, Compositae, Labiatae, and Rutaceae. The analytical results are used for the classification of different chemotypes within morphologically similar plant species. Moreover, these results could possibly open up possibilities for industrial processing and commercialization of plants with valuable constituents. Chemical data on some new Vietnamese plant oils are presented here.

\section{Materials and Methods}

\subsection{Plant Material and Isolation of the Essential Oils}

Plants were harvested in 1990-1994 during their flowering stage in the provinces of Lao Cai, Nghê An, and Huê, and in Hô Chí Minh City and Hanoi. Voucher specimens have been deposited in the herbarium of the Institute of Ecology and Natural Resources, Hanoi. The essential oils were prepared by steam distillation of fresh plant material in a glass apparatus during 3-6 h.

\subsection{Essential Oil Analyses}

The oils were investigated by capillary GC and GC/MS. GC analyses were carried out using Hewlett Packard 5710 and HP 5890 Series II gas chromatographs equipped with FID detectors. HP-1 fused silica columns $(25 \mathrm{~m} \times 0.32 \mathrm{~mm}$ i.d., $0.25 \mu \mathrm{m}$ film thickness) were used. Samples were injected by split and splitless techniques. Injector and detector temperatures were maintained at $250^{\circ} \mathrm{C}$. The column ovens were programmed from $60^{\circ} \mathrm{C}$ (after $2 \mathrm{~min}$ ) to $220^{\circ} \mathrm{C}$ at $4 \% \mathrm{~min}$ and the final temperature was held for 20 min. Peak areas and retention times were measured by electronic integration. The relative amounts of individual components are based on the peak areas obtained, without FID response factor correction.

GC/MS analyses were carried out on Hewlett-Packard 5970A and HP 5971 mass selective detectors (MSD), directly coupled 
to HP 5790A and HP 5890 gas chromatographs, respectively. 26 $\mathrm{m} \times 0.22 \mathrm{~mm}$ i.d. columns, coated with $0.13 \mu \mathrm{m}$ of $\mathrm{CP}-\mathrm{Sil} 5 \mathrm{CB}$ were employed, using helium as carrier gas. The oven temperature program was $60^{\circ} \mathrm{C}(3 \mathrm{~min})$, then $5^{\circ} / \mathrm{min}$ to $250^{\circ} \mathrm{C}$ (30 min). Other conditions were the same as described above.

The constituents of the oils were identified by matching their 70 $\mathrm{eV}$ EI mass spectra and (temperature programmed) retention indices with reference libraries and literature data [1-6]. Co-elution $\mathrm{GC}$ with reference compounds was used for confirmation of some of the compound identifications. Proton and ${ }^{13} \mathrm{C}$-NMR spectrometry were used for the structure elucidation of some major oil components if present in concentrations higher than $70 \%$.

\section{Results and Discussion}

\subsection{Labiatae Genera}

Many species of Labiatae seem to be factories for the production of various compounds necessary for our life. During the past ten years the authors have thoroughly studied many plants of this family with the help of HRGC. The endeavor to investigate so many Labiatae oils is justified because of the widespread use of these valuable oils, and is spurred by the intricate chemical composition of various chemotypes, distributed in different phyto-geographical regions.

\section{I.l Essential Oils from Elsholtzia Species}

The genus Elsholtzia (family Labiatae) is also a versatile genus, well-known for medicinal and aromatic properties. Most of the species of Elsholtzia grow wild throughout the tropical and subtropical regions of the world. Some species, like E. ciliata (Thunb.) and E. cristata Wild. are cultivated in various parts of the world. Many Elsholtzia species are used as spices and as common traditional medicine against influenza, headache, sore throat, measles, ostealgia, and furunculosis [7]. They are also haemostatic and are used to treat menorrhagia, metrorrhagia, haemoptysis, and bloody stools. The essential oils of this genus also have a broad spectrum of antimicrobial activities, a reason for exploring their potential therapeutic uses. The aim of our investigations of Elsholtzia species is, therefore, not only to reveal the chemical composition of the various essential oils, which may be helpful in their chemotaxonomy, but also to get to know the potential industrial interest in these species.

The volatile constituents of $E$. bland $a$ Benth. have been analyzed previously [8-11]. The essential oils from the aerial parts of a Chinese variety have been reported to contain 1,8-cineole (28\%) and $\alpha$-phellandrene $(9 \%)$ as major constituents $[8,9]$. Another Chinese chemotype gave oils containing linalool (33-56\%), 1,8cineole $(6-19 \%)$, and acetophenone (2-10\%) as main compounds [10]. An Indian chemotype yielded an oil containing mainly geranyl acetate $(71 \%)$. In that particular oil another 28 compounds were identified [11], of which linalool (5\%), geraniol $(4 \%)$, and $(E)-\beta$-ocimene $(3 \%)$ were the most important ones.

The volatile oil from the aerial parts of $E$. blanda Benth., grown in Vietnam, was investigated. The compounds identified in this oil are given in Table 1 with their percentage composition in the second column of this table. Thirty-four components could be identified, of which 1,8-cineole was the major constituent. The
Table 1. Percentage composition of the essential oils from four Vietnamese Elsholtzia blanda chemotypes.

\begin{tabular}{|c|c|c|c|c|}
\hline Compound $^{\text {a) }}$ & $\begin{array}{l}\text { E. blanda } \\
\text { Benth. }\end{array}$ & $\begin{array}{r}\text { E. bland } \\
\text { specimen } 1\end{array}$ & $\begin{array}{l}\text { la (Benth.) va } \\
\text { specimen } 2\end{array}$ & $\begin{array}{l}\text { Ir. spp. } \\
\text { specimen } 3\end{array}$ \\
\hline$\alpha$-tbrijene & 0.5 & $\operatorname{tr}$ & - & - \\
\hline benzaldehyde & $\operatorname{tr}$ & - & - & - \\
\hline$\alpha$-pinene & 4.3 & 2.7 & 1.5 & $\operatorname{tr}$ \\
\hline camphene & 0.9 & tr & 2.2 & $\operatorname{tr}$ \\
\hline sabinene & 2.2 & 0.8 & 0.6 & $\operatorname{tr}$ \\
\hline$\beta$-pinene & 5.9 & 7.2 & 1.0 & 0.2 \\
\hline myrcene & 1.4 & 1.3 & 0.4 & - \\
\hline$\alpha$-phellandrene & $\operatorname{tr}$ & $\operatorname{tr}$ & - & tr \\
\hline$\alpha$-terpinene & $\operatorname{tr}$ & - & $\operatorname{tr}$ & - \\
\hline$p$-cymene & 0.1 & $\operatorname{tr}$ & 0.4 & $\operatorname{tr}$ \\
\hline 1,8 -cineole & 62.0 & 52.7 & 13.4 & $\mathrm{tr}$ \\
\hline limonene & tr & 0.5 & 2.9 & - \\
\hline$(Z)$ - $\beta$-ocimene & 1.5 & 1.7 & 0.2 & - \\
\hline acetophenone & 0.1 & 0.3 & 0.1 & - \\
\hline (E)- $\beta$-ocimene & 0.6 & 0.5 & 0.3 & - \\
\hline$\alpha$-terpinene & 2.4 & $\operatorname{tr}$ & - & $\operatorname{tr}$ \\
\hline trans-sabinene hydrate & 0.6 & 0.2 & - & - \\
\hline cis-linalool oxide & - & 0.1 & - & - \\
\hline terpinolene & 0.2 & - & - & tr \\
\hline linalool & 0.3 & 14.5 & 18.7 & 0.3 \\
\hline camphor & 2.0 & - & 2.8 & $\operatorname{tr}$ \\
\hline botneol & 0.1 & - & 1.0 & tr \\
\hline terpinen-4-ol & 3.4 & 0.3 & 0.3 & 0.1 \\
\hline trans-p-menthen-2-ol & 0.6 & - & - & - \\
\hline$\alpha$-terpineol & 5.0 & 2.9 & 0.5 & $\operatorname{tr}$ \\
\hline trans-piperitol & - & - & 0.7 & - \\
\hline piperitone & 0.1 & - & 2.8 & - \\
\hline geraniol & - & 1.0 & 2.4 & - \\
\hline geranial & - & - & 0.2 & - \\
\hline bornyl acetate & $\operatorname{tr}$ & - & 1.9 & - \\
\hline geranyl acetate & - & 0.1 & 31.3 & - \\
\hline$\alpha$-copaene & 0.2 & - & - & - \\
\hline cis- $\alpha$-bergamotene & - & - & - & 2.8 \\
\hline$\beta$-caryophyllene & 2.4 & 2.3 & 4.1 & 25.3 \\
\hline trans- $\beta$-bergamotene & - & - & - & 21.6 \\
\hline trans- $\alpha$-bergamotene & 0.4 & - & - & - \\
\hline$\alpha$-humulene & 1.5 & 0.3 & 0.7 & 13.5 \\
\hline$\gamma$-muurolene & 0.4 & - & - & - \\
\hline$\alpha$-curcumene & - & - & - & 0.2 \\
\hline germacrene D & - & 2.6 & 0.8 & - \\
\hline$(E)$ - $\beta$-farnesene & - & - & - & 4.6 \\
\hline$(Z, E)$ - $\alpha$-farnesene & - & 4.4 & 3.4 & - \\
\hline$\beta$-selinene & 0.1 & - & - & - \\
\hline$\beta$-bisabolene & - & - & - & 1.8 \\
\hline$\gamma$-cadinene & 0.4 & 0.2 & - & - \\
\hline$\delta$-cadinene & 0.2 & $\operatorname{tr}$ & - & - \\
\hline$\beta$-sesquiphellandrene & - & - & - & 5.3 \\
\hline caryophyllene oxide & 0.1 & 0.2 & 0.9 & 7.0 \\
\hline$\beta$-asarone & - & - & - & 7.5 \\
\hline$\alpha$-asarone & - & - & - & 6.6 \\
\hline trimethoxybenzaldehyde & - & - & - & 1.9 \\
\hline parsley apiole & - & - & - & 0.8 \\
\hline dill apiole & - & - & - & 0.7 \\
\hline other compounds & $\mathrm{tr}$ & 2.9 & 4.5 & 0.5 \\
\hline
\end{tabular}

a) Listed in the order of elution from a HP-1 column; tr $=$ trace $=<0.1 \%$. 
oxygenated compounds ( $>70 \%$ ) play an important role in the odor of this oil. Another variety of this plant, E. blanda (Benth.) var. spp., was found in the Lào Cai area. This plant gave a high yield of essential oil ( $1.64 \%$ on the basis of dried material), which is a light yellow liquid with acceptable odor. The composition of this oil is also listed in Table 1 (third column). The oil of this species also contains mainly 1,8-cineole, but the linalool content is appreciably higher. Other compounds such as $(Z)$ - $\beta$-ocimene, trans-sabinene hydrate, cis-linalool oxide, terpinen-4-ol, $\alpha$-terpineol, geraniol, and geranyl acetate contribute to the aromatic odor of this oil.

Recently we have found another $E$. blanda (Benth.) var. spp. species in the Sapa area (Lào Cai province). The oil of this species contained geranyl acetate $(31.3 \%)$, linalool $(18.7 \%)$, and $1,8-$ cineole $(13.4 \%)$ as main constituents (see Table 1, fourth column). This oil has a special odor, like rose oil.

A fourth variety of $E$. blanda (Benth.) var. spp., distributed in the Sapa area, has been found and analyzed. Table 1 , column five, shows the percentages of the components identified in the oil of this species. The main characteristic components were sesquiterpenes, a promising value for fixative purposes.

According to their main oil constituents, the investigated specimens of Elsholtzia blanda Benth. from Vietnam can thus be classified into four chemotypes: I: 1,8-cineole (62\%), II: 1,8cineole $(53 \%)$ and linalool (15\%), III: geranyl acetate $(31 \%)$, linalool $(19 \%)$, and 1,8-cineole (13\%), and IV: the sesquiterpene (99\%) chemotype.

Table 2. Percentage composition of the essential oil from Vietnamese Elsholtzia communis (L).

\begin{tabular}{|c|c|c|c|}
\hline Compound ${ }^{a)}$ & area $\%$ & Compound & area $\%$ \\
\hline 3-methylbutanal & $\operatorname{tr}$ & $\alpha$-copaene & 0.1 \\
\hline 3-methylbutanoic acid & $\operatorname{tr}$ & $\beta$-bourbonene & 0.9 \\
\hline$\alpha$-pinene & 0.4 & $\beta$-caryophyllene & 4.5 \\
\hline camphene & 0.2 & trans- $\alpha$-bergamotene & 0.2 \\
\hline sabinene & $\operatorname{tr}$ & $\alpha$-humulene & 1.4 \\
\hline$\beta$-pinene & tr & germacrene D & 1.3 \\
\hline$\alpha$-terpinene & tr & germacrene B & 0.3 \\
\hline 1,8 -cineole & 0.1 & Y-cadinene & 0.1 \\
\hline limonene & 0.1 & $\delta$-cadinenc & 0.5 \\
\hline acetophenone & $\operatorname{tr}$ & spathulenol & 0.3 \\
\hline$\gamma$-terpinene & $\operatorname{tr}$ & caryophyllene oxide & 0.5 \\
\hline linalool & 0.2 & $\beta$-asarone & 0.4 \\
\hline camphor & tr & $\alpha$-cadinol & 0.1 \\
\hline$\alpha$-terpineol & $\operatorname{tr}$ & $\alpha$-asarone & 0.4 \\
\hline elsholtzia ketone & 82.3 & apiole & $\operatorname{tr}$ \\
\hline \multirow[t]{2}{*}{ piperitone } & $\mathrm{tr}$ & dill apiole & $\mathrm{tr}$ \\
\hline & & other compounds & 4.9 \\
\hline
\end{tabular}

\footnotetext{
a) Listed in the order of elution from a HP-I column; tr $=$ trace $=<0.1 \%$.
}

Table 3. Percentage composition of the essential oil from Vietnamese Perilla species.

\begin{tabular}{lccl}
\hline Compound $^{\text {a) }}$ & "purple" & "green" & P. frutescens \\
& Perilla & Perilla & (L.) Britt.
\end{tabular}

2-methylpropanal

1-buten-3-one

3-methylbutanal

furfural

2-ethylbutanal

$\alpha$-thujene

benzaldehyde

$\alpha$-pinene

1-octen-3-ol

$\beta$-pinene

3-octanol

myrcene

$\alpha$-terpinene

1,8-cineole

limonene

(Z)-B-ocimene

(E) $\beta$-ocimene

$\gamma$-terpinene

terpinolene

linalool

methyl salicylate

$\alpha$-terpineol

perilla ketone

isopiperitenone

perillal

(a)

Perilla

tr

tr

tr

$-$

2.8

safrole

perilla alcohol

(Z)-methyl geranate

eugenol

damascenone

methyleugenol

$\alpha$-copaene

$\beta$-bourbonene

$\beta$-elemene

$\beta$-caryophyllene

$\alpha$-humulene

germacrene $\mathrm{D}$

myristicin

$(E, E)$ - $\alpha$-farnesene

$\delta$-cadinene

elemicin

(Z)-nerolidol

caryophyllene oxide

$\delta$-cadinol

$\alpha$-cadinol

other compounds

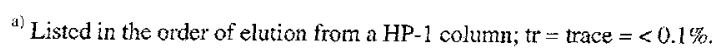


Two more species of the genus Elsholtzia from Vietnam have been investigated. Table 2 lists the chemical composition of the essential oil from E. communis (L.). No reports on the volatile constituents of this plant could be found in the literature. The analytical results show that $E$. communis (L.) from Vietnam belongs to the Elsholtzia ketone chemotype. Its volatile oil is a valuable source of elsholtzia ketone $(82.3 \%)$.

The composition of the volatile oils from $E$. ciliata grown in two different areas in Vietnam has been compared recently [12]. These oils contained geranial $(20-27 \%)$, neral $(15-21 \%)$, limonene $(11-14 \%)$, and $(Z)-\beta$-farnesene $(11-12 \%)$.

\subsubsection{Essential Oils from Perilla frutescens}

Perilla frutescens (Labiatae) is a medium sized genus of strongly scenting perennial herbs distributed in many places of Vietnam. Perilla species are used in traditional medicine and are also well known as a source of valuable compounds, which are either used as such in perfumery and allied industries, or as starting material for the synthesis of other products.

On steam distillation, the plants yield about $0.25 \%$ of essential oils. The chemical composition of the oils from "purple" and "green" Perilla is presented in Table 3. Elemicin (50.0 and $40.7 \%$ ), $\beta$-caryophyllene (20.4 and $13.6 \%$ ), and perillal (6.7 and $16.1 \%$ ) are the main constituents of these respective oils. Another local variety, $P$. frutescens (L.) Britt., however, was found to yield an oil with perilla ketone $(77.4 \%)$ as major constituent (see Table 3, last column).

Two chemotypes of $P$. frutescens had already been found previously in Vietnam $[13,14]$. From these and the present results it may be concluded that there exist at least four chemotypes of Perilla frutescens in Vietnam. The first chemotype has perillal as major constituent [13]. The second type contains mainly limonene, piperitone, and $\beta$-caryophyllene [14]. The third chemotype is rich in elemicin, perillal, and $\beta$-caryophyllene, while the fourth type is characterized by perilla ketone ( $c f$. Table 3 ). The third chemotype is reported here for the first time and is a promising source of elemicin.

\subsection{Compositae Genera}

Compositae is one of the largest, diverse, and most important families in the flora of Vietnam. Several species of this family have been used as sources of natural material for food, for the production of herbicides and growth regulators, and as drugs in traditional and modern medicine. In recent years we have studied various genera of the family Compositae such as several species of Artemisia, Ageratum, Blumea, Eupatorium, etc.

In the course of these investigations we found some typical chemotypes in Vietnam, differing substantially from chemotypes in other parts of the world. For example, the essential oil from Blumea lanceolaria (Roxb.) Druce growing in India contained $99.5 \%$ of p-cymene [15], while the oils from the Vietnamese variety contained $95.0 \%$ of methylthymol [16].

Another example is Ageratum conyzoides L. The oils from the Indian chemotypes contained mainly precocene II (syn. agerato- chromene) $[17,18]$. Plant oils from Nigeria have been reported to contain both precocene I and II as major constituents [19]. The Vietnamese chemotype also contains precocene I (29\%) and precocene II $(31 \%)$, but in addition a substantial amount of $\beta$-caryophyllene (17\%) [20].

\section{Conclusions}

Cataloguing plants by their morphological character is not sufficient for classification. Knowledge of the composition of the essential oils from (still) numerous species provides a better means for systematic classification, based on chemotaxonomy. In this report several examples of different chemotypes of otherwise morphologically similar plants have been described. HRC may thus help to increase our knowledge of the great biodiversity and, indirectly, to the conservation of numerous valuable plants.

\section{References}

[1] Y. Masada, Analysis of essential oils by gas chromatography and mass spectrometry, Wiley, New York, NY (1967)

[2] P. Sandra and C. Bicchi, Capillary gas chromatography in cssential oil analysis, Hüthig, Heidelberg, Germany (1987).

[3] L.M. Libbey, A Paradox Data Base for GCMS Data on Componcnts of Essential Oils and Other Volatiles, J. Essent. Oil Res. 3 (1991) 193.

[4] D. Henneberg, B. Weimann, and W. Joppek, Library Search System MASS-LIB, version 5.3, Max-Planck-Institut für Kohlenforschung, Mülhcim a.d. Ruhr, Germany (1989). Using this software the following data bases were searched: a) F.W. McLafferty, Wiley/NBS registry of mass spectral data, Wiley, New York, NY, 4th ed. (1988); b) D. Henneberg, B. Weimann, and W. Joppek, MPI library of mass spectral data, MaxPlanck-Institut für Kohlenforschung, Mülheim a.d. Ruhr, Germany (1989); c) M.C. ten Noever de Brauw, J. Bouwman, A.C. Tas, and G.F. La Vos, Compilation of mass spectra of volatile compounds in food, TNO-CIVO Institutes, Zeist, The Netherlands (1988).

[5] F.W. McLafferty and D.B. Stauffer, Mass spectrometry library search system BcnchTop/PBM, version 3.0, Palisade Co., Newfield, NY, (1993). Using Benchtop/PBM the following database was searched: F.W. McLafferty and D.B. Stauffer, The Wiley/NBS registry of mass spectral data, 5 th ed., Wiley and Sons, New York, NY (1991).

[6] National Institute of Standards and Technology, PC Version of the NII/EPA/NIH mass spectral database, version 4.5. U.S. Department of Commerce, Gaithersburg, MD, USA (1994).

[7] Dô Tât Loi,Medicinal Plants and Prescriptions from Vietnam, Science and Technology Publisher, Hanoi, Vielnam (1988).

[8] H. Fang, Y. Xu,, and J. Lin, Proceedings I ith International Congress on Essential Oils, Fragrances and Flavours, Nov. 1989, New Delhi, India, Vol. 4, p. 49.

[9] H. Fang, H. Duan, Y. Xu, T. Zhou, and J. Lin, Sepu 11 (1993) 69.

[10] B. Cheng, X. ma, X. Yu, and J. Ding, Yunnan Zhiwu Yanjiu 11 (1989) 91.

[11] H.J. Bestmann, J. Rauscher, O. Vostrowsky, A.K. Pant, V. Dev, R. Parihar, and C.S Mathela, J. Essent. Oil Res. 4 (1992) 121.

[12] N.X. Dung, L.V. Hac, L.H. Hái, and P.A. Leclereq, J. Esscnt. Oil Res. 7 (1995), in press.

[13] H.V. Phiet and H.T. Huong, Tâp San Hóa Hoc (J. Chem, Vietuam) 16(2) (1978) 24.

[14] N.X. Dung, L.D. Cu, L.D. Möi, and P.A. Leclercq, J. Essent. Oil Res. 7 (1995), in press. [15] S.C. Dutta, B.N. Saha, M.G. Pathak, and R.K. Mathur, Indian Perfum. 33 (1989) 38.

[16] N.X. Dung, D.T. Loi, D.T. Hùng, and P.A. Leclercy, J. Essent. Oil Res. 3 (1991) 285.

[17] E. von Rudloff and V.K. Sood, Perfum. Essential Oil Rec. 60 (1969) 303.

[18] V.K. Sood, Flavour Ind. 4 (1973) 77

[19] O. Ekundayo, I. Laakso, and R. Hiltunen, Planta Med. (1988) 55

[20] N.X. Dung, P.T.T. Tho, N.V. Dan, and P.A. Leclereq, J. Essent. Oil Res. 1 (1989) 135 Ms received: May 23, 1995 